\title{
FLUORIDATION AND THE RHEUMATIC DISEASES A COMPARISON OF RHEUMATISM IN WATFORD AND LEIGH
}

BY

\author{
B. M. ANSELL AND J. S. LAWRENCE \\ From the Medical Research Council Rheumatism Research Unit, Canadian Red Cross Memorial Hospital, Taplow, \\ and the Arthritis and Rheumatism Council Field Unit, University of Manchester
}

Although the importance of an adequate fluoride intake has been known for some time and the value of fluoride in the water supplies as a means of preventing dental decay has been established, it is necessary to ensure beyond all doubt that the procedure has no harniful effects. Kemp, Murray and Wilson (1942), in a radiological survey of a small group of persons from areas in which the water supply contained $0 \cdot 3-5 \cdot 0$ parts of fluoride per million, described irregular ossification of the epiphyseal nuclei and also of end-plates of the vertebral bodies; this was associated with the adolescent type of kyphosis in children and young adults. The suggestion was made that these findings might be associated with fluoride in the water supply combined with defective nutrition, and this led one of the authors (F. H. Kemp) to take part in another survey (Eley, Kemp, Kerley, and Berry, 1957), in which 328 boys aged 11-14 from high fluoride areas $(1 \cdot 5-5 \cdot 8$ parts per million) and a control group from low fluoride areas $(0 \cdot 1$ parts or less parts per million) were radiographed to ascertain the prevalence of Scheuermann's disease or other spinal defects. No indication that fluoride was associated with such conditions emerged. Nor were Steinberg, Gardner, Smith, and Hodge (1957) able to substantiate any relationship between musculo-skeletal disease and fluoridation of the public water supply.

In view of the report of Kemp and others (1942) and the desire to exclude the possibility that fluoridation affected the prevalence of rheumatic complaints, the Ministry of Health requested that a survey of rheumatic conditions be made in the Borough of Watford, Hertfordshire, where the water supply had been fluoridated at 1.0 part per million since May, 1956.

An area sample of some 500 persons aged 15 and over was decided upon, for comparison with a population sample in Leigh, Lancashire, examined by the Field Unit in 1954-59. Both Watford and Leigh are manufacturing towns, of some 76 thousand and 46 thousand inhabitants respectively, and both are situated on the outskirts, though separated from, large conurbations, Watford lying 17 miles to the North-West of London, and Leigh 16 miles to the North-West of Manchester. The water supply in Leigh contains less than 0.2 parts per million of fluoride, whereas Watford water now contains 1.0 part per million.

\section{Method}

Four streets were chosen at random in the Borough o Watford. These included a residential street, two housing estates, one built between the wars and the other since 1945, and finally a street near the centre of the town built before 1914. A list of inhabitants aged 15 and over was obtained from the local directory and checked by private census. It was found that 496 persons of appropriate age resided in these four streets. Following initial publicity in the press and on the radio, contact was made with these 496 persons by home visitors who arranged appointments for $x$ ray in the mobile unit placed, for this purpose, in the Town Hall Car Park. A detailed history was taken of all symptoms, present and past, and a clinical examination of the musculoskeletal system was carried out. Routine $x$ rays were taken of the hands, feet, and cervical spine; in addition, males had $x$ rays of the pelvis with suitable gonadal screening. In both sexes those aged 35 and over had $x$ rays of the lumbar spine and knees. The pelvis was $x$ rayed in females above the age of 45 . A sample of blood was taken for estimation of the sheep-cell agglutination and latex-fixation titres.

Those who were unable to attend for $x$ ray were examined at home. In these persons the lumbar spine and pelvic $x$ rays had to be omitted because of the limitations of the portable $x$ ray equipment.

The Leigh survey was made on the same lines, except that a 1 in 30 random household sample of the population was taken and $x$ rays of the pelvis were included only in those aged 55 and over. For full details of the method of sampling in Leigh, see Lawrence and Bennett (1960). 
In both the Watford and Leigh surveys, three clinicians took part, one observer being present for both surveys. All the Watford $x$ rays, together with a sample of those from Leigh, were mixed and read without knowledge of their source by one observer (J.S.L.); a sample of the Watford $x$ rays was also read by a second observer (B.M.A.).

The sera were examined by the sheep-cell agglutination test by Dr. J. Ball of the Rheumatism Research Centre, Manchester, and the latex-fixation test was carried out by Mr. A. Reading of the Canadian Red Cross Memorial Hospital, Taplow.

Completion Rate.-Of the 496 persons in the Watford survey, 356 had a clinical examination, $x$ rays, and a blood test, 57 had a clinical examination and $x$ rays only, and eight a clinical examination and blood test only. The completion rate was thus 85 per cent. Of the 75 who refused to co-operate or were not available, a number were examined clinically but have not been used in the analyses which follow since no objective data are available. Similarly, in Leigh, the completion-rate for those who had either an $x$ ray or a bood test was 86 per cent. (Table I). The main difference lies in the number, totalling 54 in Watford, who had $x$ rays but refused to give blood. The age distribution of the Watford respondents differed slightly from that in Leigh (Table II); a correction for age distribution has therefore been made in the Tables which follow, the expected rate for the Watford sample being assessed from the Leigh sample by adjustment to the Watford age distribution.

TABLE II

AGE AND SEX DISTRIBUTION OF RESPONDENTS IN WATFORD AND LEIGH SAMPLES

\begin{tabular}{|c|c|c|c|c|c|c|}
\hline \multirow{2}{*}{\multicolumn{3}{|c|}{$\underset{\text { (yrs) }}{\text { Age Group }}$}} & \multicolumn{2}{|c|}{ Males } & \multicolumn{2}{|c|}{ Females } \\
\hline & & & Watford & Leigh & Watford & Leigh \\
\hline $\begin{array}{l}15-24 \\
25-34 \\
35-44 \\
45-54 \\
55-64 \\
65+ \\
\end{array}$ & $\begin{array}{l}. \\
\cdots \\
\cdots \\
\cdots \\
.\end{array}$ & $\begin{array}{l}. \\
\therefore \\
\therefore \\
\therefore\end{array}$ & $\begin{array}{l}39 \\
40 \\
26 \\
43 \\
32 \\
22\end{array}$ & $\begin{array}{r}105 \\
119 \\
107 \\
151 \\
93 \\
78\end{array}$ & $\begin{array}{l}35 \\
46 \\
30 \\
41 \\
32 \\
35\end{array}$ & $\begin{array}{r}106 \\
106 \\
124 \\
152 \\
112 \\
89\end{array}$ \\
\hline Total & . & .. & 202 & 653 & 219 & 689 \\
\hline
\end{tabular}

\section{Total Rheumatic Complaints \\ Results}

Of the Watford males, 99 stated that at some time they had had rheumatic symptoms (Table III, opposite).

The expected number, as determined from the Leigh sample was 125 , a significant difference $(P \simeq$ 을 $0 \cdot 04$ ). Of the Watford females, 134 had at some time had rheumatic complaints compared with an $\frac{\bar{\sigma}}{\partial}$ expected number of 141 . The diminished prevalence $\stackrel{\curvearrowright}{\circledR}$ was not found in the older age group, being present only in those under the age of 55. A history of loss of work due to rheumatic complaints was given by 25. males and 31 females compared with an expected $56 \overrightarrow{\vec{\omega}}$ males and 54 females in Leigh $(P<0.01)$. The difference was present in all age groups in both $\frac{2}{2}$ males and females. In Watford those incapaci-i tated for 3 months or more were eight males and $r$ eight females, compared with an expected 22 and $\vec{\sigma}$ sixteen. Rheumatic complaints at the time of interview were present in 33 males and 56 females, 은 again below the expected rate. Only two males and one female were actually off work because of rheumatic trouble at the time of the survey; all three had been off work for at least 3 months, one man with rheumatoid arthritis and the other with $\vec{\varphi}$ lumbar disk prolapse and spinal osteoporos: and the woman with disk degeneration possib\$ associated with rheumatoid arthritis of the spine.

\section{Prevalence of Rheumatoid Arthritis}

Rheumatoid arthritis was assessed in the Watford $\stackrel{D}{Q}_{2}$ population by three methods:

(1) A grading from 0 to 4 for rheumatoid $\overrightarrow{\vec{O}}$ arthritis was given immediately after the clinical examination.

(2) A grading from 0 to 4 for radiological evidence of erosive arthritis was given on all $x$ rays regardless of the clinical grading.

(3) The A.R.A. criteria (Ropes, Bennett, Cobb, Jacox and, Jessar, 1958) as modified in Rome for population studies (Kellgren, Jeffrey, and $\frac{2}{3}$ Ball, 1963) were assessed from the clinical and 0 radiological findings and the results of serum tests.

TABLE I

COMPLETION RATE IN WATFORD AND LEIGH SURVEYS

\begin{tabular}{|c|c|c|c|c|c|c|c|c|c|c|}
\hline \multicolumn{4}{|c|}{ Survey } & $\begin{array}{c}\text { Total } \\
\text { in } \\
\text { Sample }\end{array}$ & $\begin{array}{c}\text { Refused to } \\
\text { Co-operate } \\
\text { or Not } \\
\text { Available } \\
\end{array}$ & $\begin{array}{c}x \text { ray } \\
\text { and } \\
\text { Blood } \\
\text { Test }\end{array}$ & $\underset{\text { Only }}{\boldsymbol{x} \text { ray }}$ & $\begin{array}{l}\text { Blood } \\
\text { Test } \\
\text { Only }\end{array}$ & $\begin{array}{c}\boldsymbol{x} \text { ray } \\
\text { and/or } \\
\text { Blood } \\
\text { Test }\end{array}$ & $\begin{array}{c}\text { Completion } \\
\text { Rate } \\
\text { (per cent.) }\end{array}$ \\
\hline $\begin{array}{l}\text { Watford } \\
\text { Leigh }\end{array}$ & 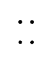 & $\cdots$ & $\begin{array}{l}. . \\
\cdots\end{array}$ & $\begin{array}{r}496 \\
1,565\end{array}$ & $\begin{array}{r}75 \\
222\end{array}$ & $\begin{array}{r}356 \\
1,239\end{array}$ & $\begin{array}{l}57 \\
72\end{array}$ & $\begin{array}{r}8 \\
31\end{array}$ & $\begin{array}{r}421 \\
1,342\end{array}$ & $\begin{array}{l}85 \\
86\end{array}$ \\
\hline
\end{tabular}

,


TABLE III

RHEUMATIC COMPLAINTS IN WATFORD POPULATION SAMPLE COMPARED WITH NUMBER EXPECTED FROM LEIGH SAMPLE, BY AGE AND SEX

\begin{tabular}{|c|c|c|c|c|c|c|c|c|c|c|c|c|c|c|}
\hline \multirow{3}{*}{ Sex } & \multirow{3}{*}{$\underset{\text { Group }}{\text { Age }}$} & \multirow{3}{*}{$\begin{array}{l}\text { Total } \\
\text { Exam- } \\
\text { ined }\end{array}$} & \multicolumn{6}{|c|}{ Since Birth } & \multicolumn{6}{|c|}{ At Time of Interview } \\
\hline & & & \multicolumn{2}{|c|}{$\begin{array}{c}\text { Total } \\
\text { with } \\
\text { Complaints }\end{array}$} & \multicolumn{2}{|c|}{$\begin{array}{c}\text { Pain } \\
\text { Off work } \\
1 \text { week } \\
\text { or more }\end{array}$} & \multicolumn{2}{|c|}{$\begin{array}{l}\text { Off work } \\
3 \text { months } \\
\text { or more }\end{array}$} & \multicolumn{2}{|c|}{$\begin{array}{c}\text { Total } \\
\text { with } \\
\text { Complaints }\end{array}$} & \multicolumn{2}{|c|}{$\begin{array}{c}\text { Pain } \\
\text { Off work } \\
1 \text { week } \\
\text { or more }\end{array}$} & \multicolumn{2}{|c|}{$\begin{array}{l}\text { Off work } \\
3 \text { months } \\
\text { or more }\end{array}$} \\
\hline & & & Actual & Expected & Actual & ixpected & Actual & Expected & Actual & Expected & Actual & xpected & Actual & Expected \\
\hline \multirow[t]{2}{*}{ Male } & $\begin{array}{r}15-24 \\
25-34 \\
35-44 \\
45-54 \\
55-64 \\
65+\end{array}$ & $\begin{array}{l}39 \\
40 \\
26 \\
43 \\
32 \\
22\end{array}$ & $\begin{array}{r}9 \\
16 \\
9 \\
23 \\
25 \\
17\end{array}$ & $\begin{array}{l}11 \cdot 3 \\
23 \cdot 7 \\
16 \cdot 1 \\
31 \cdot 0 \\
24 \cdot 3 \\
16 \cdot 3\end{array}$ & $\begin{array}{r}1 \\
4 \\
0 \\
10 \\
5 \\
5\end{array}$ & $\begin{array}{c}1 \cdot 95 \\
5 \cdot 6 \\
5 \cdot 7 \\
20 \cdot 3 \\
15 \cdot 0 \\
7 \cdot 1\end{array}$ & $\begin{array}{l}1 \\
1 \\
0 \\
3 \\
2 \\
1\end{array}$ & $\begin{array}{l}0 \cdot 78 \\
1 \cdot 2 \\
1 \cdot 8 \\
6 \cdot 9 \\
7 \cdot 4 \\
3 \cdot 38\end{array}$ & $\begin{array}{r}2 \\
3 \\
1 \\
10 \\
11 \\
6\end{array}$ & $\begin{array}{r}4 \cdot 7 \\
9 \cdot 2 \\
6 \cdot 5 \\
15 \cdot 5 \\
15 \cdot 4 \\
6 \cdot 6\end{array}$ & $\begin{array}{l}1 \\
0 \\
0 \\
0 \\
1 \\
0\end{array}$ & $\begin{array}{l}0 \\
0 \\
0 \\
1 \cdot 29 \\
0 \cdot 35 \\
0 \cdot 29\end{array}$ & $\begin{array}{l}1 \\
0 \\
0 \\
0 \\
1 \\
0\end{array}$ & $\begin{array}{l}0 \\
0 \\
0 \\
0 \cdot 86 \\
0 \cdot 35 \\
0 \cdot 29\end{array}$ \\
\hline & Total & 202 & 99 & $124 \cdot 7$ & 25 & $55 \cdot 6$ & 8 & $21 \cdot 5$ & 33 & $47 \cdot 9$ & 2 & $1 \cdot 9$ & 2 & $1 \cdot 5$ \\
\hline \multirow[t]{2}{*}{ Female } & $\begin{array}{r}15-24 \\
25-34 \\
35-44 \\
45-54 \\
55-64 \\
65+\end{array}$ & $\begin{array}{l}35 \\
46 \\
30 \\
41 \\
32 \\
35\end{array}$ & $\begin{array}{l}10 \\
16 \\
16 \\
33 \\
29 \\
30\end{array}$ & $\begin{array}{r}8 \cdot 1 \\
26 \cdot 2 \\
19 \cdot 8 \\
32 \cdot 8 \\
28 \cdot 0 \\
26 \cdot 2\end{array}$ & $\begin{array}{l}1 \\
2 \\
3 \\
8 \\
9 \\
8\end{array}$ & $\begin{array}{c}2 \cdot 1 \\
6 \cdot 45 \\
6 \cdot 9 \\
14 \cdot 6 \\
14 \cdot 4 \\
9 \cdot 5\end{array}$ & $\begin{array}{l}0 \\
1 \\
1 \\
3 \\
2 \\
1\end{array}$ & $\begin{array}{l}0 \cdot 31 \\
0 \cdot 46 \\
1 \cdot 8 \\
2 \cdot 46 \\
5 \cdot 1 \\
5 \cdot 9\end{array}$ & $\begin{array}{r}3 \\
5 \\
6 \\
13 \\
14 \\
15\end{array}$ & $\begin{array}{r}3 \cdot 9 \\
7 \cdot 8 \\
12 \cdot 3 \\
19 \cdot 3 \\
20 \cdot 5 \\
17 \cdot 9\end{array}$ & $\begin{array}{l}0 \\
0 \\
0 \\
1 \\
0 \\
0\end{array}$ & $\begin{array}{l}0 \\
0 \\
0 \cdot 3 \\
0 \cdot 41 \\
0.96 \\
1.5\end{array}$ & $\begin{array}{l}0 \\
0 \\
0 \\
1 \\
0 \\
0\end{array}$ & $\begin{array}{l}0 \\
0 \\
0 \\
0 \cdot 27 \\
0 \cdot 58 \\
1 \cdot 16\end{array}$ \\
\hline & Total & 219 & 134 & $141 \cdot 1$ & 31 & $53 \cdot 9$ & 8 & $15 \cdot 9$ & 56 & $81 \cdot 7$ & 1 & $3 \cdot 2$ & 1 & $2 \cdot 0$ \\
\hline
\end{tabular}

On the clinical grading rheumatoid arthritis. Grade 2 to 4, was present in five males and six females, the expected number judged from the population of Leigh being four and twelve (Table IV). The difference in prevalence between Watford and Leigh is not significant even in females $(?-3 \cdot 3 \mathrm{P} \simeq 0.06)$.

Using the A.R.A. criteria, none of the males and three of the females had "definite" disease, and probable or definite disease was present in three males and nine females (Table V). By these criteria also there was thus rather less rheumatoid arthritis than in Leigh, since five males and thirteen females would be expected to have probable or definite disease in a population of this age distribution.

Since clinical assessment including the use of the $8 \mathscr{\circ}$ A.R.A. criteria is subject to observer difference, it is

TABLE IV

CLINICAL RHEUMATOID ARTHRITIS IN WATFORD POPULATION SAMPLE, BY AGE AND SEX

\begin{tabular}{|c|c|c|c|c|c|c|c|c|c|c|c|c|c|c|c|c|}
\hline \multirow{3}{*}{$\begin{array}{c}\text { Age } \\
\text { Group } \\
\text { (yrs) }\end{array}$} & \multicolumn{8}{|c|}{ Males } & \multicolumn{8}{|c|}{ Females } \\
\hline & \multirow{2}{*}{$\begin{array}{c}\text { Total } \\
\text { Examined }\end{array}$} & \multicolumn{5}{|c|}{ Grade } & \multicolumn{2}{|c|}{ Grade $2-4$} & \multirow{2}{*}{$\begin{array}{c}\text { Total } \\
\text { Examined }\end{array}$} & \multicolumn{5}{|c|}{ Grade } & \multicolumn{2}{|c|}{ Grade $2-4$} \\
\hline & & 0 & 1 & 2 & 3 & 4 & Actual & Expected* & & 0 & 1 & 2 & 3 & 4 & Actual & Expected* \\
\hline $\begin{array}{r}15-24 \\
25-34 \\
35-44 \\
45-54 \\
55-64 \\
65+\end{array}$ & $\begin{array}{l}39 \\
40 \\
26 \\
43 \\
32 \\
22\end{array}$ & $\begin{array}{l}38 \\
40 \\
25 \\
38 \\
24 \\
15\end{array}$ & $\begin{array}{l}0 \\
0 \\
1 \\
3 \\
8 \\
5\end{array}$ & $\begin{array}{l}0 \\
0 \\
0 \\
2 \\
0 \\
2\end{array}$ & $\begin{array}{l}1 \\
0 \\
0 \\
0 \\
0 \\
0\end{array}$ & $\begin{array}{l}0 \\
0 \\
0 \\
0 \\
0 \\
0\end{array}$ & $\begin{array}{l}1 \\
0 \\
0 \\
2 \\
0 \\
2\end{array}$ & $\begin{array}{l}0 \\
0.68 \\
0.49 \\
1.42 \\
1.02 \\
0.56\end{array}$ & $\begin{array}{l}35 \\
46 \\
30 \\
41 \\
32 \\
34\end{array}$ & $\begin{array}{l}33 \\
45 \\
25 \\
35 \\
22 \\
23\end{array}$ & $\begin{array}{l}2 \\
1 \\
4 \\
5 \\
8 \\
9\end{array}$ & $\begin{array}{l}0 \\
0 \\
1 \\
1 \\
2 \\
1\end{array}$ & $\begin{array}{l}0 \\
0 \\
0 \\
0 \\
0 \\
1\end{array}$ & $\begin{array}{l}0 \\
0 \\
0 \\
0 \\
0 \\
0\end{array}$ & $\begin{array}{l}0 \\
0 \\
1 \\
1 \\
2 \\
2\end{array}$ & $\begin{array}{l}0 \\
1 \cdot 29 \\
1 \cdot 04 \\
1 \cdot 08 \\
4 \cdot 26 \\
3 \cdot 76\end{array}$ \\
\hline Total & 202 & 180 & 17 & 4 & 1 & 0 & 5 & $4 \cdot 17$ & 218 & 183 & 29 & 5 & 1 & 0 & 6 & $12 \cdot 4$ \\
\hline
\end{tabular}

* From Leigh sample.

TABLE V

ARA CRITERIA IN WATFORD POPULATION SAMPLE, BY AGE AND SEX

\begin{tabular}{|c|c|c|c|c|c|c|c|c|c|c|c|c|}
\hline \multirow{3}{*}{$\begin{array}{c}\text { Age } \\
\text { Group } \\
\text { (yrs) }\end{array}$} & \multicolumn{6}{|c|}{ Males } & \multicolumn{6}{|c|}{ Females } \\
\hline & \multirow{2}{*}{$\begin{array}{c}\text { Total } \\
\text { Examined }\end{array}$} & \multirow{2}{*}{$\begin{array}{lll}\text { None } \\
0 & 1 & 2\end{array}$} & \multirow{2}{*}{$\left|\begin{array}{cc}\text { Probable } \\
3 & 4\end{array}\right|$} & \multirow{2}{*}{$\underset{5}{\text { Definite }}$} & \multicolumn{2}{|c|}{ Probable + Definite } & \multirow{2}{*}{$\begin{array}{c}\text { Total } \\
\text { Examined }\end{array}$} & \multirow{2}{*}{$\begin{array}{l}\text { None } \\
0 \\
0\end{array} 12$} & \multirow{2}{*}{$\underset{3}{\text { Probable }}$} & \multirow{2}{*}{$\begin{array}{c}\text { Definite } \\
5\end{array}$} & \multicolumn{2}{|c|}{ Probable + Definite } \\
\hline & & & & & Actual & Expected & & & & & Actual & Expected \\
\hline $\begin{array}{r}15-24 \\
25-34 \\
35-44 \\
45-54 \\
55-64 \\
65+\end{array}$ & $\begin{array}{l}39 \\
39 \\
25 \\
42 \\
32 \\
22\end{array}$ & $\begin{array}{rrr}36 & 2 & 0 \\
38 & 1 & 0 \\
21 & 3 & 1 \\
28 & 12 & 2 \\
20 & 11 & 0 \\
13 & 6 & 2\end{array}$ & $\begin{array}{ll}1 & 0 \\
0 & 0 \\
0 & 0 \\
0 & 0 \\
1 & 0 \\
0 & 1\end{array}$ & $\begin{array}{l}\mathbf{0} \\
0 \\
0 \\
0 \\
0 \\
0\end{array}$ & $\begin{array}{l}1 \\
0 \\
0 \\
0 \\
1 \\
1\end{array}$ & $\begin{array}{l}0 \cdot 23 \\
0 \cdot 39 \\
0 \cdot 25 \\
1 \cdot 26 \\
1 \cdot 60 \\
0 \cdot 88\end{array}$ & $\begin{array}{l}35 \\
46 \\
30 \\
41 \\
32 \\
34\end{array}$ & $\begin{array}{rrr}33 & 2 & 0 \\
42 & 3 & 1 \\
24 & 4 & 1 \\
30 & 5 & 5 \\
15 & 9 & 4 \\
14 & 12 & 5 \\
\end{array}$ & $\begin{array}{ll}\mathbf{0} & \mathbf{0} \\
\mathbf{0} & \mathbf{0} \\
\mathbf{1} & \mathbf{0} \\
\mathbf{0} & \mathbf{1} \\
\mathbf{2} & \mathbf{1} \\
\mathbf{0} & \mathbf{1} \\
\end{array}$ & $\begin{array}{l}0 \\
0 \\
0 \\
0 \\
1 \\
2\end{array}$ & $\begin{array}{l}0 \\
0 \\
1 \\
1 \\
4 \\
3\end{array}$ & $\begin{array}{l}0 \\
0 \\
0 \cdot 60 \\
1 \cdot 64 \\
4 \cdot 80 \\
5 \cdot 45\end{array}$ \\
\hline$\overline{\text { Total }}$ & 199 & 156355 & 21 & 0 & 3 & $4 \cdot 6$ & 218 & 1583516 & 33 & 3 & 9 & $12 \cdot 5$ \\
\hline
\end{tabular}


important that a radiological check be made before definite conclusions can be drawn between the prevalence of rheumatoid arthritis in different population samples.

Of the males in Watford, twelve ( 6 per cent.) had radiological evidence of erosive arthritis Grade 2 to 4 in the joints of the hands or feet, compared with 7.6 expected in Leigh, and six ( 3 per cent.) had involvement of the cervical spine, compared with $7 \cdot 2$ expected in Leigh (Table VI). Of the females in Watford, nine (4 per cent.) had involvement of the joints of the hands or feet compared with 7.0 expected in Leigh and fourteen ( 7 per cent.) had cervical involvement compared with $7 \cdot 3$ expected in Leigh. Only one male and one female had Grade 3 to 4 changes, the man in the feet and the woman in the cervical spine. There was thus no significant difference between Leigh and Watford as regards erosive arthritis in the peripheral joints or neck.

\section{Rheumatoid Serum Factors}

The sheep cell agglutination test was positive at a titre of 1 in 32 in only one male (0.6 per cent.) and three $(1.7$ per cent.) females in the Watford sample (Table VII), the expected numbers being five (3.6 per cent.) and eight ( $4 \cdot 8$ per cent.) respectively.
There were thus significantly fewer positive tests i i Watford $(\mathrm{P}<0.02)$. The relationship to age noted in previous surveys was also present in Watform The one male with a positive test was over 64 and the three females were all over 44 . One male anep one female with a positive test had rheumatoid: arthritis; the male had radiological evidence only and the female had both clinical and radiologicat evidence. The titre distribution in Watford was unusual in that 93 per cent of the population showed no agglutination even at a titre of 1 in 4 (Figure opposite).

The latex-fixation test was negative in the 277 serᄅ्ठ tested, which unfortunately included only one of the four with a positive S.C.A.T.

The relationship of clinical to radiologicas evidence of rheumatoid arthritis and to the S.C.A.T. is shown in Table VIII (opposite).

Of the two persons with Grade 3 clinical arthritis, one had definite radiological evidence of erosions i卬 the feet; the other had pain and swelling of the finger joints but only a small erosion in one

TABLE VI

RADIOLOGICAL EVIDENCE OF EROSIVE ARTHRITIS IN WATFORD, BY AGE AND SEX

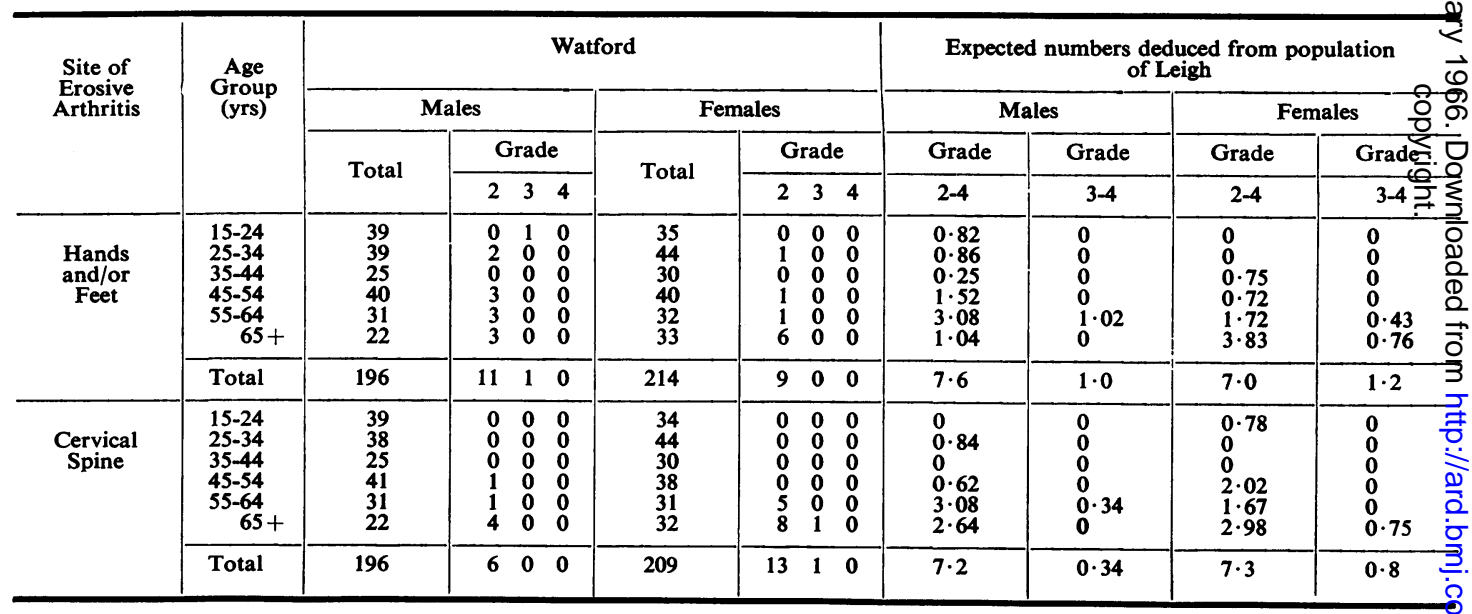

TABLE VII

S.C.A.T. IN WATFORD POPULATION SAMPLE, BY AGE AND SEX

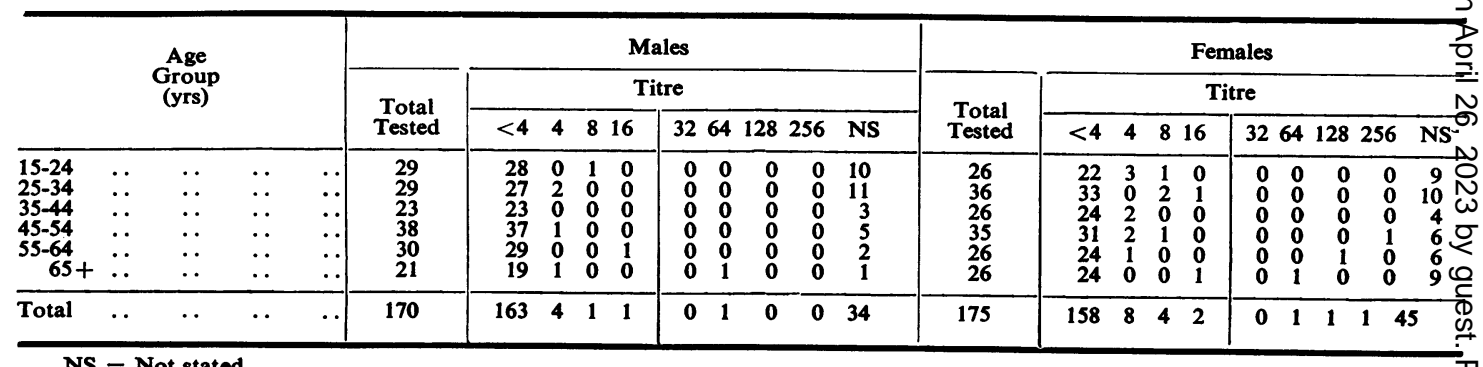

NS $=$ Not stated 
TABLE VIII

RELATIONSHIP OF CLINICAL TO RADIOLOGICAL EVIDENCE OF R.A. (GRADES 2 AND 3) IN WATFORD SAMPLE

\begin{tabular}{|c|c|c|c|c|c|c|c|}
\hline & & & & \multicolumn{4}{|c|}{ Grade of Rheumatoid Arthritis } \\
\hline \multirow{2}{*}{\multicolumn{4}{|c|}{ Evidence of R.A. }} & \multicolumn{2}{|c|}{2} & \multicolumn{2}{|c|}{3} \\
\hline & & & & Total & S.C.A.T. Positive & Total & S.C.A.T. Positive \\
\hline $\begin{array}{l}\text { Clinical Only } \ldots \\
\text { Radiological Only } \\
\text { Clinical and Radiological }\end{array}$ & $\begin{array}{l}\cdots \\
\cdots\end{array}$ & $\begin{array}{l}\ldots \\
\cdots\end{array}$ & $\begin{array}{l}\cdots \\
\cdots \\
\cdots\end{array}$ & $\begin{array}{r}7 \\
42 \\
2\end{array}$ & $\begin{array}{l}0 \\
1 \\
1\end{array}$ & $\begin{array}{l}1 \\
1 \\
1\end{array}$ & $\begin{array}{c}0 \\
\text { NS } \\
0\end{array}$ \\
\hline
\end{tabular}

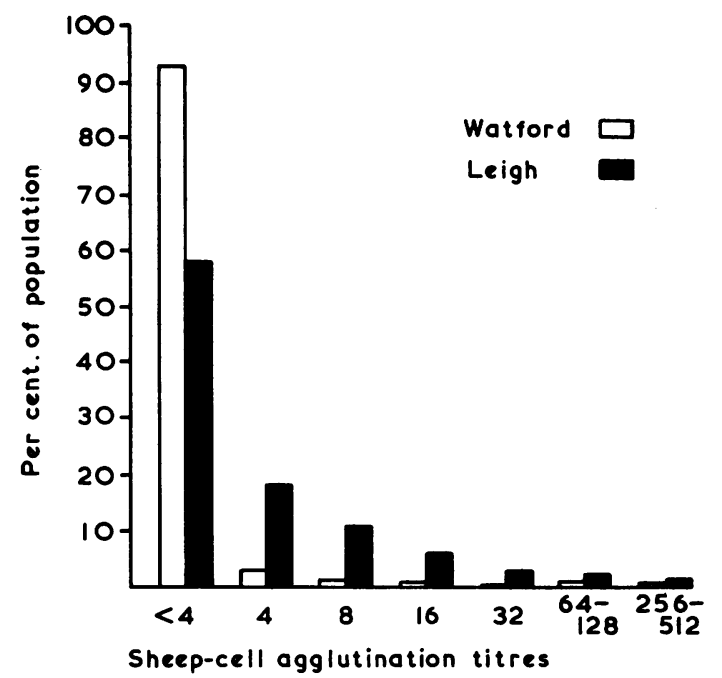

Fig.

metacarpo-phalangeal joint and slight subluxation of the twelfth dorsal and first lumbar vertebrae, and was not regarded as having definite rheumatoid arthritis from the $x$ rays. A third person had Grade 3 arthritis of the cervical spine on $x$ ray and a history of pain in the hands, but was not thought to have clinical rheumatoid arthritis; she refused a blood test. Of the nine persons with Grade 2 clinical disease, two had radiological change, one with a positive S.C.A.T.; in the other seven the serum tests were negative. There were 42 with minimal radiological erosions but no clinical evidence, one with a positive S.C.A.T.; most of these had erosive arthritis in the hands or feet, or in the cervical spine.

\section{Other Rheumatic Disorders}

At the initial clinical examination only one male and none of the females in Watford was given a diagnosis of spondylitis. By the Rome criteria (Kellgren and others, 1963), the one male had definite spondylitis. The prevalence was thus 5 per 1,000 in males which may be compared with the figure of 4 per 1,000 in the males of Leigh and
Wensleydale. Two males were considered to be suffering from gout. This is the expected prevalence. None had definite gout by the Rome criteria, each having only one positive criterion.

\section{Prevalence of Osteo-arthrosis}

Osteo-arthrosis was graded $\mathbf{0}$ to $\mathbf{4}$ for each group of joints, the grade of the worst affected joint being recorded. All the D.I.P. joints were considered to be in one group as were all the P.I.P. joints and so on. In this way, the joints $x$ rayed were divided into fourteen groups. The number of joint groups in which there was at least a Grade 2 osteo-arthrosis is shown for the Watford sample and for Leigh in Table IX (overleaf).

Of the Watford males, twelve (6 per cent.) haфॄ osteo-arthrosis in five or more groups of joints compared with 7 per cent. in Leigh. Of the Watfor $\overline{\$}$ females, 21 (10 per cent.) had five or more groups of joints affected compared with 14 per cent. in Leigh, an insignificant difference. Nor was there any significant difference in the more severe grades in males, but females had less frequent multiple osteo-arthrosis Grade 3 to 4 affecting five or more joints in Watford than in Leigh; the difference was not significant (Table $\mathrm{X}$, overleaf).

\section{Prevalence of Disk Degeneration}

Cervical disk degeneration Grade 3 to 4 was present in 37 of the Watford males, whereas 42 would have been expected (Table XI, overleaf); there was thus no significant difference between the two populations in males. The Watford females had more disk degeneration than those in Leigh, 37 having Grade 3 to 4 changes, compared with 25 expected. This was found chiefly in the older age groups, from 55 years of age onwards, but was not significant at the 5 per cent. level.

Lumbar disk degeneration was present in almost identical proportions in Leigh and Watford, sixteen males (19 per cent.) and thirteen females (15 per cent.) having moderate or severe change, compared with an expected fourteen and eleven respectively (Table XI). 인 $+$ ั) $\stackrel{\frac{c}{2}}{2}$ $\overrightarrow{0}$ 
TABLE IX

NUMBER OF JOINT GROUPS WITH OSTEO-ARTHROSIS GRADE 2-4, BY AGE AND SEX

\begin{tabular}{|c|c|c|c|c|c|c|c|c|c|c|c|c|c|c|c|c|c|c|c|c|c|c|c|c|c|c|}
\hline \multirow{2}{*}{ Survey } & \multirow{2}{*}{$\underset{\text { (yrs) }}{\text { Age }}$} & \multicolumn{12}{|c|}{ Males } & \multicolumn{13}{|c|}{ Females } \\
\hline & & Total & $\begin{array}{ll}0 & 1\end{array}$ & 2 & 3 & 4 & 5 & 6 & 7 & 8 & & $10+$ & $\begin{array}{c}5 \\
\text { (per } \\
\text { cent.) }\end{array}$ & Total & 0 & 1 & 2 & 3 & 4 & 5 & 6 & 7 & 8 & & $10+$ & $\begin{array}{c}5: \\
\text { (per } \\
\text { cent.) }\end{array}$ \\
\hline \multirow{3}{*}{ Watford } & $\begin{array}{l}15-24 \\
25-34 \\
35-44 \\
\end{array}$ & $\begin{array}{r}39 \\
38 \\
25 \\
\end{array}$ & $\begin{array}{ll}37 & 2 \\
31 & 5 \\
16 & 6 \\
\end{array}$ & & $\begin{array}{l}0 \\
0 \\
1 \\
\end{array}$ & & & & & & & & & $\begin{array}{l}35 \\
44 \\
30 \\
\end{array}$ & $\begin{array}{l}32 \\
34 \\
22 \\
\end{array}$ & $\begin{array}{r}3 \\
10 \\
8 \\
\end{array}$ & & & & & & & & & & \\
\hline & $\begin{array}{r}45-54 \\
55-64 \\
65+ \\
\end{array}$ & $\begin{array}{l}40 \\
31 \\
22 \\
\end{array}$ & $\begin{array}{rr}18 & 11 \\
6 & 7 \\
1 & 1 \\
\end{array}$ & $\begin{array}{l}7 \\
5 \\
3 \\
\end{array}$ & $\begin{array}{l}2 \\
6 \\
3 \\
\end{array}$ & $\begin{array}{l}2 \\
4 \\
5 \\
\end{array}$ & $\begin{array}{l}2 \\
2 \\
\end{array}$ & $\begin{array}{l}\mathbf{0} \\
\mathbf{3} \\
\end{array}$ & $\begin{array}{l}1 \\
0 \\
\end{array}$ & $\begin{array}{l}0 \\
3 \\
\end{array}$ & 1 & $\begin{array}{l}0 \\
0 \\
\end{array}$ & & $\begin{array}{l}40 \\
31 \\
33 \\
\end{array}$ & $\begin{array}{r}17 \\
2 \\
1 \\
\end{array}$ & $\begin{array}{r}13 \\
9 \\
3 \\
\end{array}$ & & $\begin{array}{l}2 \\
5 \\
5 \\
\end{array}$ & $\begin{array}{l}1 \\
3 \\
7 \\
\end{array}$ & & $\begin{array}{l}3 \\
7 \\
\end{array}$ & $\begin{array}{l}0 \\
4 \\
\end{array}$ & $\begin{array}{l}0 \\
1 \\
\end{array}$ & $\begin{array}{l}0 \\
0 \\
\end{array}$ & & \\
\hline & Total & 195 & 10932 & 20 & 121 & 11 & 4 & 3 & 1 & 3 & 1 & 0 & 6 & 213 & & & & 121 & 14 & & 10 & 4 & 1 & 0 & 0 & 10 \\
\hline \multirow{3}{*}{ Leigh } & $\begin{array}{l}15-24 \\
25-34 \\
35-44\end{array}$ & $\begin{array}{l}39 \\
39 \\
25 \\
\end{array}$ & $\begin{array}{rr}34 & 5 \\
28 & 10 \\
14 & 8 \\
\end{array}$ & & $\begin{array}{l}0 \\
0 \\
0 \\
\end{array}$ & $\begin{array}{l}0 \\
0 \\
0 \\
\end{array}$ & & & & & & & & $\begin{array}{l}35 \\
44 \\
30 \\
\end{array}$ & $\begin{array}{r}22 \\
29 \\
7 \\
\end{array}$ & & & $\begin{array}{l}0 \\
2 \\
1 \\
\end{array}$ & & & & & & & & \\
\hline & $\begin{array}{c}45-54 \\
55-64 \\
65+\end{array}$ & $\begin{array}{l}41 \\
30 \\
22\end{array}$ & $\begin{array}{rr}12 & 11 \\
1 & 5 \\
3 & 1\end{array}$ & $\begin{array}{l}9 \\
8 \\
2\end{array}$ & $\begin{array}{l}4 \\
5 \\
6\end{array}$ & $\begin{array}{l}3 \\
4 \\
4\end{array}$ & $\begin{array}{l}1 \\
2 \\
2\end{array}$ & $\begin{array}{l}0 \\
3 \\
1\end{array}$ & $\begin{array}{l}0 \\
1 \\
2\end{array}$ & $\begin{array}{l}1 \\
0\end{array}$ & 1 & $\begin{array}{l}0 \\
0 \\
0\end{array}$ & & $\begin{array}{l}40 \\
32 \\
33\end{array}$ & $\begin{array}{l}3 \\
0 \\
1\end{array}$ & $\begin{array}{l}7 \\
6 \\
0\end{array}$ & $\begin{array}{r}19 \\
7 \\
3\end{array}$ & $\begin{array}{l}9 \\
6 \\
5\end{array}$ & \begin{tabular}{l|}
1 \\
7 \\
5
\end{tabular} & $\begin{array}{l}2 \\
2 \\
8\end{array}$ & $\begin{array}{l}1 \\
2 \\
2\end{array}$ & $\begin{array}{l}0 \\
0 \\
2\end{array}$ & $\begin{array}{l}1 \\
1 \\
6\end{array}$ & $\begin{array}{l}0 \\
0 \\
0\end{array}$ & $\begin{array}{l}1 \\
1 \\
1\end{array}$ & \\
\hline & Total & 196 & 9241 & 23 & 151 & & 5 & 4 & 3 & 1 & 1 & 0 & 7 & 214 & 62 & & & 231 & & 12 & 5 & 2 & 8 & 0 & 2 & 14 \\
\hline
\end{tabular}

TABLE X

NUMBER OF JOINT GROUPS WITH OSTEO-ARTHRITIS GRADE 3-4 IN PERSONS AGED 55 AND OVER, BY SEX

\begin{tabular}{|c|c|c|c|c|c|c|c|c|c|c|c|c|c|c|c|c|c|c|c|c|c|c|}
\hline \multirow{2}{*}{ Survey } & \multirow{2}{*}{\multicolumn{2}{|c|}{$\underset{\text { Group }}{\text { Agrs) }}$}} & & & & \multicolumn{9}{|c|}{ Males } & \multicolumn{8}{|c|}{ Females } \\
\hline & & & & & & Total & 0 & 1 & 2 & 3 & 4 & 5 & 6 & $7+$ & Total & 01 & 2 & 3 & 4 & 5 & 6 & 7 \\
\hline \multirow[t]{2}{*}{ Watford } & $\begin{array}{c}55-64 \\
65\end{array}$ & & 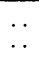 & 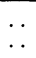 & $\begin{array}{l}. . \\
. .\end{array}$ & $\begin{array}{l}31 \\
22\end{array}$ & $\begin{array}{r}21 \\
8\end{array}$ & $\begin{array}{l}6 \\
4\end{array}$ & $\begin{array}{l}4 \\
4\end{array}$ & $\begin{array}{l}0 \\
1\end{array}$ & $\begin{array}{l}0 \\
4\end{array}$ & $\begin{array}{l}0 \\
2\end{array}$ & $\begin{array}{l}0 \\
0\end{array}$ & $\begin{array}{l}0 \\
0\end{array}$ & 32 & $\begin{array}{rr}20 & 8 \\
9 & 15\end{array}$ & $\begin{array}{l}3 \\
3\end{array}$ & $\frac{1}{2}$ & $\begin{array}{l}0 \\
3\end{array}$ & $\begin{array}{l}0 \\
1\end{array}$ & $\begin{array}{l}0 \\
0\end{array}$ & $\begin{array}{l}0 \\
0\end{array}$ \\
\hline & Total & $\ldots$ & $\ldots$ & $\ldots$ & $\ldots$ & 53 & 29 & 10 & 8 & 1 & 4 & 2 & 0 & 0 & 65 & 2923 & 6 & 3 & 3 & 1 & 0 & 0 \\
\hline \multirow[t]{2}{*}{ Leigh } & $\begin{array}{r}55-64 \\
65+\end{array}$ & $\begin{array}{l}. \\
.\end{array}$ & $\because$ & $\ldots$ & 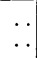 & $\begin{array}{l}30 \\
22\end{array}$ & $\begin{array}{l}17 \\
11\end{array}$ & $\begin{array}{l}8 \\
8\end{array}$ & $\begin{array}{l}3 \\
2\end{array}$ & $\begin{array}{l}1 \\
0\end{array}$ & $\begin{array}{l}1 \\
1\end{array}$ & $\begin{array}{l}0 \\
0\end{array}$ & $\begin{array}{l}0 \\
0\end{array}$ & $\begin{array}{l}0 \\
0\end{array}$ & $\begin{array}{l}32 \\
33\end{array}$ & $\begin{array}{rr}15 & 11 \\
11 & 6\end{array}$ & $\begin{array}{l}5 \\
4\end{array}$ & $\begin{array}{l}0 \\
6\end{array}$ & $\begin{array}{l}0 \\
1\end{array}$ & $\frac{1}{2}$ & $\begin{array}{l}0 \\
2\end{array}$ & 0 \\
\hline & Total & $\ldots$ & $\ldots$ & $\ldots$ & $\ldots$ & 52 & 28 & 16 & 5 & 1 & 2 & 0 & 0 & 0 & 65 & 2617 & 9 & 6 & 1 & 3 & 2 & 10 \\
\hline
\end{tabular}

TABLE XI

RADIOLOGICAL EVIDENCE OF DISK GENERATION IN WATFORD

COMPARED WITH THAT EXPECTED FROM LEIGH SURVEY BY SITE, AGE, AND SEX

\begin{tabular}{|c|c|c|c|c|c|c|c|c|c|c|c|c|c|c|}
\hline \multirow{3}{*}{$\begin{array}{c}\begin{array}{c}\text { Site of } \\
\text { Disk } \\
\text { Degeneration }\end{array} \\
\text { Dention }\end{array}$} & \multirow{3}{*}{ Sex } & \multirow{3}{*}{$\underset{\text { Group }}{\text { Age }}$} & & & \multirow{3}{*}{$\begin{array}{c}\text { Total } \\
x \text { rayed }\end{array}$} & \multicolumn{7}{|c|}{ Grade of Disk Degeneration } & & \\
\hline & & & & & & \multirow{2}{*}{\multicolumn{2}{|c|}{$\begin{array}{ll}0 & 1\end{array}$}} & \multirow{2}{*}{\multicolumn{2}{|c|}{23}} & & \multicolumn{2}{|c|}{$2-4$} & \multicolumn{2}{|c|}{$3-4$} \\
\hline & & & & & & & & & & & Actual & Expected & Actual & Expected \\
\hline \multirow{4}{*}{ Cervical } & \multirow[t]{2}{*}{ Male } & $\begin{array}{c}15-24 \\
25-34 \\
35-44 \\
45-54 \\
55-64 \\
65+\end{array}$ & $\begin{array}{l}. \\
\therefore \\
\therefore \\
\therefore\end{array}$ & $\begin{array}{l}\ldots \\
\ldots \\
\ldots \\
\ldots\end{array}$ & $\begin{array}{l}39 \\
38 \\
25 \\
41 \\
31 \\
22\end{array}$ & $\begin{array}{r}38 \\
33 \\
20 \\
18 \\
9 \\
0\end{array}$ & $\begin{array}{l}0 \\
2 \\
1 \\
4 \\
2 \\
2\end{array}$ & $\begin{array}{r}1 \\
3 \\
4 \\
10 \\
7 \\
5\end{array}$ & $\begin{array}{r}0 \\
0 \\
0 \\
9 \\
12 \\
15\end{array}$ & $\begin{array}{l}0 \\
0 \\
0 \\
0 \\
1 \\
0\end{array}$ & & & & \\
\hline & & Total & .. & . & 196 & 1181 & & 30 & 36 & 1 & 67 & 81 & 37 & 42 \\
\hline & \multirow[t]{2}{*}{ Female } & $\begin{array}{c}15-24 \\
25-34 \\
35-44 \\
45-54 \\
55-64 \\
65+ \\
\end{array}$ & $\begin{array}{l}. \\
\therefore \\
\therefore \\
\therefore\end{array}$ & $\begin{array}{l}. \\
\therefore \\
\therefore \\
\therefore\end{array}$ & $\begin{array}{l}34 \\
44 \\
30 \\
38 \\
31 \\
32 \\
\end{array}$ & $\begin{array}{r}34 \\
38 \\
21 \\
15 \\
4 \\
2 \\
\end{array}$ & $\begin{array}{l}0 \\
2 \\
2 \\
4 \\
1 \\
1\end{array}$ & $\begin{array}{r}0 \\
4 \\
6 \\
11 \\
12 \\
15\end{array}$ & $\begin{array}{r}0 \\
0 \\
1 \\
7 \\
14 \\
13 \\
\end{array}$ & $\begin{array}{l}0 \\
0 \\
0 \\
1 \\
0 \\
1\end{array}$ & & $\begin{array}{l}0 \cdot 78 \\
1 \cdot 94 \\
3 \\
20 \\
16 \cdot 4 \\
22\end{array}$ & & $\begin{array}{l}0 \\
0 \\
0 \cdot 75 \\
9 \cdot 5 \\
7 \cdot 0 \\
8 \cdot 0\end{array}$ \\
\hline & & Total & .. & .. & 209 & 1141 & & 483 & 35 & 2 & 85 & 64 & 37 & 25 \\
\hline \multirow{4}{*}{ Lumbar } & \multirow[t]{2}{*}{ Male } & $\begin{array}{r}35-44 \\
45-54 \\
55-64 \\
65+ \\
\end{array}$ & $\begin{array}{l}. \\
\because \\
.\end{array}$ & $\begin{array}{l}. \\
\therefore \\
\therefore \\
\end{array}$ & $\begin{array}{l}15 \\
28 \\
25 \\
15 \\
\end{array}$ & $\begin{array}{r}6 \\
10 \\
2 \\
2 \\
\end{array}$ & $\begin{array}{l}3 \\
2 \\
2 \\
0 \\
\end{array}$ & $\begin{array}{r}6 \\
14 \\
13 \\
7 \\
\end{array}$ & $\begin{array}{l}0 \\
2 \\
6 \\
5 \\
\end{array}$ & $\begin{array}{l}0 \\
0 \\
2 \\
1 \\
\end{array}$ & & $\begin{array}{r}6 \cdot 7 \\
20 \cdot 0 \\
21 \\
13 \cdot 4 \\
\end{array}$ & & $\begin{array}{l}0 \cdot 45 \\
3 \cdot 1 \\
6 \cdot 3 \\
3 \cdot 9 \\
\end{array}$ \\
\hline & & Total & .. &. & 83 & 20 & 7 & 40 & 13 & 3 & 56 & 61 & 16 & 14 \\
\hline & \multirow[t]{2}{*}{ Female } & $\begin{array}{c}35-44 \\
45-54 \\
55-64 \\
65+ \\
\end{array}$ & $\begin{array}{l}. \\
\therefore \\
\end{array}$ & $\begin{array}{l}\therefore \\
\therefore \\
\therefore\end{array}$ & $\begin{array}{l}21 \\
29 \\
23 \\
15 \\
\end{array}$ & $\begin{array}{r}11 \\
13 \\
9 \\
3 \\
\end{array}$ & $\begin{array}{l}2 \\
2 \\
0 \\
0 \\
\end{array}$ & $\begin{array}{r}6 \\
10 \\
10 \\
9 \\
\end{array}$ & $\begin{array}{l}2 \\
4 \\
4 \\
3 \\
\end{array}$ & $\begin{array}{l}\begin{array}{l}0 \\
0 \\
0 \\
0\end{array} \\
\end{array}$ & & $\begin{array}{r}5 \cdot 7 \\
16.6 \\
16.6 \\
8 \cdot 8 \\
\end{array}$ & & $\begin{array}{l}0 \\
3 \cdot 0 \\
4 \cdot 6 \\
2 \cdot 9 \\
\end{array}$ \\
\hline & & Total & .. & .. & 88 & 36 & 4 & 351 & 13 & 0 & 48 & 48 & 13 & 11 \\
\hline
\end{tabular}




\section{Prevalence of Osteoporosis}

Osteoporosis was graded 0 to 4 in all the Watford and Leigh $x$ rays. Only in the hand $x$ rays was a standard bone included, so that the assessment was probably more reliable in the hands than elsewhere. Two Watford males ( 1 per cent.) had Grade 2 to 4 osteoporosis of the hands, whereas $2 \cdot 3$ would have been expected (Table XII). Five Watford females ( 2 per cent.) had Grade 2 to 4 change compared with an expected 22; a highly significant difference $(\mathbf{P}<0 \cdot 01)$. Similarly, osteoporosis in the cervical spine showed little difference between Watford and Leigh in the males but was significantly less frequent in the Watford females, of whom only six ( 3 per cent.) had Grade 2 to 4 osteoporosis compared with an expected eighteen $(P \simeq 0 \cdot 01)$. Lumbar osteopo- rosis showed the same prevalence in the two areas but in view of the difficulty of assessing osteoporosis in the lumbar spine from radiographs this result must be accepted with caution.

\section{Effect of Renal Disease}

As a special group, three Watford residents with known renal disease were also studied:

(1) A man aged 24 had been diagnosed as having idiopathic pulmonary haemosiderosis with renal involvement. Renal biopsy showed that two-thirds of the renal glomeruli were abnormal, some showing basement membrane thickening, others partial hyalinization. His urea clearance was between 129.9 and $134.4 \mathrm{ml} . / \mathrm{min}$. and blood urea 29 to $36 \mathrm{mg}$. $/ 100 \mathrm{ml}$. Apart from back pain he had no musculoskeletal symptoms or signs, and the

TABLE XII

OSTEOPOROSIS IN WATFORD COMPARED WITH EXPECTED PREVALENCE FROM LEIGH RANDOM SAMPLE, BY SITE, AGE AND SEX

\begin{tabular}{|c|c|c|c|c|c|c|c|c|c|c|c|c|}
\hline \multirow{3}{*}{$\begin{array}{c}\text { Site } \\
\text { of } \\
\text { Osteoporosis }\end{array}$} & \multirow{3}{*}{ Sex } & \multirow{3}{*}{$\begin{array}{c}\text { Age } \\
\text { Group } \\
\text { (yrs) }\end{array}$} & & & \multirow{3}{*}{$\begin{array}{l}\text { Total } \\
x \text { rayed }\end{array}$} & \multicolumn{7}{|c|}{ Grade of Osteoporosis } \\
\hline & & & & & & \multirow{2}{*}{0} & \multirow{2}{*}{1} & \multirow{2}{*}{2} & \multirow{2}{*}{3} & \multirow{2}{*}{4} & \multicolumn{2}{|c|}{$2-4$} \\
\hline & & & & & & & & & & & Actual & Expected \\
\hline \multirow{4}{*}{ Hands } & \multirow[t]{2}{*}{ Male } & $\begin{array}{cc}15-24 & \ldots \\
25-34 & \ldots \\
35-44 & \ldots \\
45-54 & \ldots \\
55-64 & \ldots \\
65 & + \\
\end{array}$ & $\begin{array}{l}\ldots \\
\cdots \\
\cdots \\
\cdots\end{array}$ & $\begin{array}{l}\because \\
\therefore \\
\therefore \\
\therefore \\
.\end{array}$ & $\begin{array}{l}39 \\
38 \\
25 \\
40 \\
31 \\
22\end{array}$ & $\begin{array}{l}39 \\
38 \\
24 \\
40 \\
30 \\
21\end{array}$ & $\begin{array}{l}0 \\
0 \\
1 \\
0 \\
0 \\
0\end{array}$ & $\begin{array}{l}\mathbf{0} \\
0 \\
0 \\
0 \\
0 \\
1\end{array}$ & $\begin{array}{l}0 \\
0 \\
0 \\
0 \\
1 \\
0\end{array}$ & $\begin{array}{l}\mathbf{0} \\
\mathbf{0} \\
\mathbf{0} \\
\mathbf{0} \\
\mathbf{0} \\
\mathbf{0} \\
\end{array}$ & & 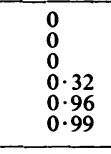 \\
\hline & & Total .. & .. & .. & 195 & 184 & 1 & 1 & 1 & $\mathbf{0}$ & 2 & $2 \cdot 3$ \\
\hline & \multirow[t]{2}{*}{ Female } & $\begin{array}{cc}15-24 & \cdots \\
25-34 & \cdots \\
35-44 & \cdots \\
45-54 & \cdots \\
55-64 & \cdots \\
65+\end{array}$ & $\begin{array}{l}. \\
\cdots \\
\cdots \\
\cdots \\
\cdots\end{array}$ & $\begin{array}{l}. . \\
\therefore \\
\therefore \\
\therefore \\
.\end{array}$ & $\begin{array}{l}35 \\
44 \\
30 \\
40 \\
32 \\
33 \\
\end{array}$ & $\begin{array}{l}35 \\
43 \\
30 \\
40 \\
31 \\
26 \\
\end{array}$ & $\begin{array}{l}0 \\
1 \\
0 \\
0 \\
1 \\
2 \\
\end{array}$ & $\begin{array}{l}0 \\
0 \\
0 \\
0 \\
0 \\
5 \\
\end{array}$ & $\begin{array}{l}0 \\
0 \\
0 \\
0 \\
0 \\
0 \\
\end{array}$ & $\begin{array}{l}\mathbf{0} \\
\mathbf{0} \\
\mathbf{0} \\
\mathbf{0} \\
\mathbf{0} \\
\mathbf{0} \\
\end{array}$ & & $\begin{array}{l}0 \\
0 \\
0 \\
0 \cdot 88 \\
8 \cdot 3 \\
12 \cdot 9 \\
\end{array}$ \\
\hline & & Total ... & .. &.. & 214 & 205 & 4 & 5 & 0 & 0 & 5 & $22 \cdot 1$ \\
\hline \multirow{4}{*}{ Cervical Spine } & \multirow[t]{2}{*}{ Male } & $\begin{array}{cc}15-24 & \ldots \\
25-34 & \cdots \\
35-44 & \cdots \\
45-54 & \cdots \\
55-64 & \cdots \\
65+ \\
\end{array}$ & $\begin{array}{l}\ldots \\
\cdots \\
\cdots \\
\cdots \\
\cdots\end{array}$ & $\begin{array}{l}. \\
\because \\
\therefore \\
\therefore \\
-\end{array}$ & $\begin{array}{l}39 \\
38 \\
25 \\
41 \\
31 \\
22 \\
\end{array}$ & $\begin{array}{l}39 \\
34 \\
25 \\
36 \\
29 \\
19 \\
\end{array}$ & $\begin{array}{l}0 \\
4 \\
0 \\
3 \\
0 \\
2 \\
\end{array}$ & $\begin{array}{l}0 \\
0 \\
0 \\
2 \\
1 \\
1 \\
\end{array}$ & $\begin{array}{l}\mathbf{0} \\
\mathbf{0} \\
0 \\
0 \\
1 \\
0 \\
\end{array}$ & $\begin{array}{l}\mathbf{0} \\
\mathbf{0} \\
\mathbf{0} \\
\mathbf{0} \\
\mathbf{0} \\
\mathbf{0} \\
\end{array}$ & & $\begin{array}{l}0 \\
0 \\
0 \cdot 25 \\
0 \cdot 66 \\
1 \cdot 0 \\
0 \cdot 51 \\
\end{array}$ \\
\hline & & Total ... &. &.. & 196 & 182 & 9 & 4 & 1 & $\mathbf{0}$ & 5 & $2 \cdot 42$ \\
\hline & \multirow[t]{2}{*}{ Female } & $\begin{array}{cc}15-24 & \ldots \\
25-34 & \ldots \\
35-44 & \ldots \\
45-54 & \ldots \\
55-64 & \ldots \\
65+ \\
\end{array}$ & $\begin{array}{l}\cdots \\
\cdots \\
\cdots \\
\cdots \\
\cdots\end{array}$ & $\begin{array}{l}. . \\
\because \\
\cdots \\
\cdots \\
.\end{array}$ & $\begin{array}{l}34 \\
44 \\
30 \\
38 \\
31 \\
32 \\
\end{array}$ & $\begin{array}{l}34 \\
44 \\
28 \\
36 \\
29 \\
22 \\
\end{array}$ & $\begin{array}{l}0 \\
0 \\
1 \\
1 \\
1 \\
7 \\
\end{array}$ & $\begin{array}{l}0 \\
0 \\
1 \\
1 \\
1 \\
3 \\
\end{array}$ & $\begin{array}{l}\mathbf{0} \\
\mathbf{0} \\
\mathbf{0} \\
\mathbf{0} \\
\mathbf{0} \\
\mathbf{0} \\
\end{array}$ & $\begin{array}{l}0 \\
0 \\
0 \\
0 \\
0 \\
0 \\
\end{array}$ & & $\begin{array}{c}0 \\
0 \\
0 \\
1 \cdot 68 \\
5 \cdot 9 \\
10 \cdot 7 \\
\end{array}$ \\
\hline & & Total ... &. &. & 209 & 193 & 10 & 6 & $\mathbf{0}$ & 0 & 6 & $18 \cdot 28$ \\
\hline \multirow{4}{*}{ Lumbar Spine } & \multirow[t]{2}{*}{ Male } & $\begin{array}{r}35-44 \\
45-54 \\
55-64 \\
65+ \\
6\end{array}$ & $\begin{array}{l}\cdots \\
\cdots \\
\cdots \\
\end{array}$ & $\begin{array}{l}\cdots \\
\cdots \\
\cdots \\
\end{array}$ & $\begin{array}{l}15 \\
28 \\
25 \\
15 \\
\end{array}$ & $\begin{array}{l}15 \\
24 \\
19 \\
11 \\
\end{array}$ & $\begin{array}{l}0 \\
2 \\
4 \\
3 \\
\end{array}$ & $\begin{array}{l}0 \\
2 \\
1 \\
1 \\
\end{array}$ & $\begin{array}{l}0 \\
0 \\
1 \\
0 \\
\end{array}$ & $\begin{array}{l}\mathbf{0} \\
\mathbf{0} \\
\mathbf{0} \\
\mathbf{0} \\
\end{array}$ & & $\begin{array}{l}0 \cdot 33 \\
0 \cdot 92 \\
0 \cdot 43 \\
3 \cdot 2 \\
\end{array}$ \\
\hline & & Total .. & $\cdots$ & $\therefore$ & 83 & 69 & 9 & 4 & 1 & 0 & 5 & $4 \cdot 88$ \\
\hline & \multirow[t]{2}{*}{ Female } & $\begin{array}{cc}35-44 & \ldots \\
45-54 & \cdots \\
55-64 & \cdots \\
65+\end{array}$ & $\begin{array}{l}\cdots \\
\cdots \\
\cdots\end{array}$ & $\begin{array}{l}\because . \\
\cdots \\
\therefore \\
\end{array}$ & $\begin{array}{l}21 \\
29 \\
23 \\
15 \\
\end{array}$ & $\begin{array}{r}20 \\
21 \\
15 \\
5 \\
\end{array}$ & $\begin{array}{l}1 \\
5 \\
4 \\
5 \\
\end{array}$ & $\begin{array}{l}0 \\
2 \\
2 \\
4 \\
\end{array}$ & $\begin{array}{l}0 \\
1 \\
2 \\
1 \\
\end{array}$ & $\begin{array}{l}\mathbf{0} \\
\mathbf{0} \\
\mathbf{0} \\
\mathbf{0} \\
\end{array}$ & & $\begin{array}{l}0 \\
0 \cdot 73 \\
4 \cdot 1 \\
6 \cdot 3 \\
\end{array}$ \\
\hline & & Total .. & $\cdots$ &. & 88 & 61 & 15 & 8 & 4 & 0 & 12 & $11 \cdot 13$ \\
\hline
\end{tabular}


$x$ rays showed no abnormality in the spine, hands, or pelvis.

(2) A man aged 66 with diabetes and secondary glomerulo-sclerosis had proteinuria and a blood urea of $80 \mathrm{mg} . / 100 \mathrm{ml}$. He complained of pain in the shoulders which were limited in all movements, as were the hips. The $x$ rays showed generalized osteoarthrosis of minimal severity but no sclerotic changes.

(3) A woman aged 69, who had had her left kidney removed 2 years previously because of hydronephrosis, had hypertension and pitting oedema of the ankles. Her blood urea was $50 \mathrm{mg} . / 100 \mathrm{ml}$. She complained of back pain and had degenerative changes in the 1st and 5th lumbar disks but no sclerosis or new bone formation.

\section{Discussion}

It is clear from the findings in this survey that the prevalence of rheumatic disease was no greater in Watford, where 1 part of fluoride per million had been added to the water supply for the previous 5 years, than in Leigh, where the water contains negligible quantities of fluoride.

The lower frequency of rheumatic complaints in Watford cannot be explained by differences in memory since the prevalence was less at the time of the survey as well as in the past. The difference in incapacity in the two populations is also against a memory difference. Climatic influences may have played a part. The average rainfall in Watford is 24 in. per annum compared with 34 in. in Leigh, and the hours of sunshine 1,460 per annum in Watford compared with 1,070 in Leigh. It would be expected, however, that climate would influence mainly those with the degenerative forms of rheumatism, since complaints in these forms depend to a great extent on the pain threshold (Lawrence, 1955). Observer difference may have played a part. Only 70 males and 77 females were questioned by the observer who took part in the Leigh survey. In Watford a history of rheumatic complaints was elicited in 39 men ( 56 per cent.) and 50 women (65 per cent.) seen by this observer. This is rather more than in the sample as a whole but slightly less than the expected 45 males and 53 females. This may well have been due to a change of grading by this observer. The only objective evidence of diminished rheumatic disease was that related to osteoporosis and it would seem unlikely that this is responsible for the difference in rheumatic complaints in Leigh and Watford, since osteoporosis occurs only in the older age groups and mainly in females, and rheumatic complaints were diminished in both sexes and in females mainly in the younger age group.

The reason for the low prevalence of osteoporosis in the Watford population cannot be determined on the present evidence; it would seem unlikely that the्ष addition of fluoride to the water supply is respon $\frac{5}{3}$ sible, although Leone, Stevenson, Besse, Hawes, and Dawber (1960) found a higher prevalence of severe? osteoporosis in Birmingham, where the fluoride content of the water was 0.04 p.p.m., than in the surveys in the towns of Bartlett and Cameron, where the content was 8.0 and 0.4 p.p.m. respectively흘 Moreover, Posner (1965) found increased crystaf size in bones of persons from high fluoride areas The administration of fluoride to osteoporotiक patients has not, however, been found to affect the calcium balance (Rose, 1965).

The low sheep cell agglutination titres in the्ष Watford sample calls for some comment. IT several surveys of populations in Northern Europes de Graaff, Laine, and Lawrence (1963) found fewer positive sheep cell agglutination titres in the rura $\$$ than in the urban populations. Watford is larges than Leigh but specializes in lighter industry and has less atmospheric pollution. A possible relationship of the sheep cell factor to atmospheric pollution is at present under review.

\section{Summary}

(1) A population sample in the town of Watfơ Hertfordshire, has been examined clinically, radiơo gically, and serologically to determine the prevalence of chronic rheumatic diseases. A comparison has been made with a population sample in Leigh Lancashire. The water supply in Watford ha been fluoridated during the previous 5 years whereas in Leigh the water contained only nego ligible amounts of fluoride.

(2) There was no increased prevalence of rheuê matoid arthritis, osteo-arthrosis, spondylitis, gou? or disk degeneration, and indeed, rheumatic com plaints as a whole and incapacity due to rheue matism were significantly less in Watford than in Leigh.

(3) The prevalence of positive sheep cell aggluti nation titres and latex-fixation titres in Watford was. significantly lower than expected.

(4) There was a diminished prevalence of osteoporosis as judged from hand and cervicat radiographs in the Watford females compared witb those in Leigh, that in males being similar in each area.

We wish to express our thanks to the Ministry of Health for a grant towards the cost of this surveyp Dr. W. Alcock, Medical Officer of Health, Watfor $\$$ 
for his help, and Profs. E. G. L. Bywaters and J. H. Kellgren for their advice and criticism. We also owe a debt of gratitude to the people of Watford who took part in this survey.

\section{REFERENCES}

De Graaff, R., Laine, V., and Lawrence, J. S. (1963). In "The Epidemiology of Chronic Rheumatism", ed. J. H. Kellgren, M. Jeffreys, and J. Ball, vol. 1, p. 228. Blackwell, Oxford.

Eley, A. J., Kemp, F. H., Kerley, P. J., and Berry, W. T. C. (1957). Lancet, 2, 712.

Kellgren, J. H., Jeffrey, M., and Ball, J. (1963). In "The Epidemiology of Chronic Rheumatism", vol. 1, p. 324. Blackwell, Oxford.

Kemp, F. H., Murray, M. M., and Wilson, D. C. (1942). Lancet, 2, 93.

Lawrence, J. S. (1955). Brit. J. industr. Med., 12, 249.

— and Bennett, P. H. (1960). Ann. rheum. Dis., 19, 20.

Leone, N. C., Stevenson, C. A., Besse, B., Hawes, L. E., and Dawber, T. R. (1960). A.M.A. Arch. industr. Hlth, 21, 326.

Posner, A. S. (1965). New Scientist, 26, 242.

Ropes, M. W., Bennett, G. A., Cobb, S., Jacox, R. and Jessar, R. A. (1958). Bull. rheum. Dis., 9, 175.

Rose, G. A. (1965). Proc. roy. Soc. Med., 58, 436.

Steinberg, C. K., Gardner, D. E., Smith, F. A. and Hodge, H. C. (1957). Cited by Johnson, L. G., Mackenzie, K. R., and Vaillancourt, de Guise, Bull. rheum. Dis., 8, 145.

Fluoration des eaux de boisson et les maladics rhumatismales.-Etude comparée de deux villes anglaises, Watford et Leigh

\section{RÉSUMÉ}

(1) On examina du point de vue clinique, radiologique et sérologique un échantillon de la population de la ville de Watford, en Hertfordshire, pour déterminer la fréquence des maladies rhumatismales chroniques. On compara les résultats avec ceux obtenus de la même manière à Leigh, Lancashire. Les eaux de boisson de
Watford sont fluorées depuis cinq ans, tandis que l'eau potable à Leigh ne contient que des quantités negligeables de fluor.

(2) On ne trouva pas de fréquence augmentée d'arthrite rhumatismale, d'ostéoarthrite, de spondylarthrite, de dégénérescence du disque et, au fait, de manifestations rhumatismales quelconques. L'incapacité due au rhumatisme fut significativement moindre à Watford qu'à Leigh.

(3) Les réactions de Waaler-Rose et de fixation au latex positives furent significativement en dessous de l'espérance mathématique.

(4) La fréquence d'ostéoporose, estimée d'après les radiographies des mains et des vertèbres cervicales, fut moindre chez les femmes de Watford que chez celles de Leigh. Pour les hommes, cette fréquence fut la même dans les deux villes.

Fluoración del agua potable y las enfermedades reumáticas. Una comparación de dos ciudades inglesas, Watford y Leigh

\section{SUMARIO}

(1) Se examinó clínica, radiológica y serológicamente una muestra de la población de la ciudad de Watford, Hertfordshire, para determinar la frecuencia de las enfermedades reumáticas crónicas. Se compararon los resultados con los obtenidos de la misma manera en la ciudad de Leigh, Lancashire. En Watford se añade fluor al agua potable desde cinco años, mientras que el aqua potable en Leigh contiene sólo cantidades desdeñables de este elemento.

(2) No se encontró frecuencia aumentada de artritis reumatoide, osteoartritis, espondilitis, degeneración discal o otras cualquieras manifestaciones reumáticas. La incapacidad debida al reumatismo fué significativamente men or en Watford que en Leigh.

(3) Las reacciones de Waaler-Rose y de fijación al latex positivas fueron significativamente debajo de las previstas estadísticamente.

(4) La frecuencia de la osteoporosis, según radiografías de manos y de columnas cervicales, fué menor en mujeres de Watford que en las de Leigh, pero no se encontró tal diferencia entre los hombres de estas ciudades. 